\title{
KAUSALITAS KONTRIBUSI INDUSTRI PARIWISATA DAN JUMLAH KUNJUNGAN WISATAWAN TERHADAP PERTUMBUHAN EKONOMI
}

\author{
Cokorda Bagus Yudistira $^{1 \S}$, I Wayan Sumarjaya ${ }^{2}$, Luh Putu Ida Harini ${ }^{3}$ \\ ${ }^{1}$ Program Studi Matematika, Fakultas MIPA - Universitas Udayana [Email: cokyudistira@ gmail.com] \\ ${ }^{2}$ Program Studi Matematika, Fakultas MIPA - Universitas Udayana [Email: sumarjaya@unud.ac.id] \\ ${ }^{3}$ Program Studi Matematika, Fakultas MIPA - Universitas Udayana [Email: ballidah@unud.ac.id] \\ ${ }^{\S}$ Corresponding Author
}

\begin{abstract}
Bali is known as one of the most popular tourism destination in the world. The number of tourist visit to Bali increases every year. In 2010, there roughly 7 millions tourist visits to Bali and reach up to 14 million people by the end of 2017. This increased in number may affect the growth of tourism industries and economic growth in Bali Province. This study aims to analyze the patterns of causal relationship between tourism industry receipts, tourist visits, and economic growth in Bali based on time series data using vector autoregressive (VAR) model. The results conclude the following: (i) foreign tourist visits is significantly affect economic growth. In addition, economic growth, domestic tourist visits, and foreign tourist visits are significantly impact to tourism industry receipts, (ii) economic growth would affect the tourism industry receipts in the next four consecutive months, (iii) the forecasting result of economic growth with VAR model is highly accurated with MAPE $2 \%$.
\end{abstract}

Keywords: causality, tourism industry receipts, economic growth, tourists visits, Bali Province

\section{PENDAHULUAN}

Data deret waktu (time series) adalah sekumpulan pengamatan yang disusun dalam urutan waktu seperti data tahunan, triwulanan, dan bulanan. Dalam data deret waktu dapat diamati pola-pola tertentu, pola yang sama bisa saja terjadi secara berulang karena kondisi saat ini bisa dipengaruhi oleh kondisi sebelumnya. Salah satu model deret waktu multivariate yang sering digunakan adalah vector autoregressive (VAR), model ini digunakan untuk menganalisis hubungan dinamis dari sejumlah variabel secara simultan dari peubah-peubah deret waktu yang stasioner.

Model vector autoregressive (VAR) umum digunakan dalam sistem peramalan dari data deret waktu (time series) yang saling berhubungan dan untuk menganalisis dampak dinamis dari sistem dengan sejumlah variabel. Model VAR menyusun setiap variabel endogen dalam sistem sebagai fungsi beda kala dari setiap variabel endogen lainnya dalam model (Eviews, 2017).
Pariwisata saat ini sudah menjadi bagian yang tidak terpisahkan dalam kehidupan manusia baik dalam kegiatan sosial maupun ekonomi. Pariwisata telah berkembang menjadi salah satu sektor ekonomi terbesar di dunia. Berbagai destinasi pariwisata pun telah dibuat dan dikembangkan di berbagai belahan dunia. Salah satu destinasi pariwisata di Indonesia yang paling diminati adalah pulau Bali. Setiap tahun jumlah kunjungan wisatawan ke Bali terus mengalami peningkatan. Berdasarkan data BPS, pada tahun 2010 jumlah kunjungan wisatawan nusantara (wisnus) ke Bali sebanyak 4,65 juta jiwa dan wisatawan mancanegara (wisman) 2,58 juta jiwa. Jumlah ini terus meningkat hingga pada akhir tahun 2017 jumlah kunjungan wisnus mencapai 8,64 juta jiwa disusul oleh jumlah wisman yang mencapai 5,7 juta jiwa. Meningkatnya jumlah kunjungan wisatawan ini otomatis akan memberikan dampak positif bagi perekonomian pulau Bali karena dapat membantu perkembangan jasa dan industri 
pariwisata.

Pertumbuhan ekonomi regional dapat diamati dari pertumbuhan nilai produk domestik regional bruto (PDRB). Untuk mengukur laju pertumbuhan ekonomi indikator yang digunakan adalah PDRB atas dasar harga konstan (ADHK). Struktur PDRB Provinsi Bali tersusun atas pendapatan dari 17 sektor lapangan usaha. Menurut BPS (2017), sektor penyediaan akomodasi dan makan minum merupakan sektor dengan keterkaitan paling besar terhadap pariwisata yang memberi share paling dominan bagi PDRB Bali bahkan menunjukkan kecenderungan yang terus meningkat dari tahun ke tahun

Selain sebagai sumber pendapatan devisa, pariwisata juga memberikan kontribusi untuk penciptaan lapangan kerja, kegiatan produksi dan pendapatan nasional (PDB), pertumbuhan sektor swasta dan pembangunan infrastruktur. Meskipun beragam kontribusi pariwisata terhadap perekonomian telah disadari sejak lama namun sejauh ini penelit ian tentang pengaruh pariwisata terhadap pertumbuhan ekonomi belum mendapatkan porsi yang cukup besar, sehingga sulit menentukan arah hubungan antar kedua variabel. Berdasarkan fakta tersebut, studi ini ingin menganalisis hubungan antara jumlah wisman, jumlah kunjungan wisnus, dan pendapatan industri pariwisata terhadap PDRB Provinsi Bali dan meramalkan nilai PDRB Provinsi Bali periode Juli 2017—Desember 2017.

\section{TINJAUAN PUSTAKA}

\section{a. Kestasioneran}

Menurut Gujarati (2008) suatu proses stokastik dikatakan stasioner apabila mean dan varians yang konstan sepanjang waktu (time invariant) dan nilai kovarians hanya bergantung pada beda kala (lag) antara dua periode waktu. Proses $y_{t}$ dikatakan stasioner lemah (weakly stationary) jika memenuhi:

1. $E\left(y_{t}\right)=\mu$,

2. $\operatorname{var}\left(y_{t}\right)=E\left(y_{t}-\mu\right)^{2}=\sigma^{2}$,

3. $\operatorname{cov}\left(y_{t}, y_{t+s}\right)=E\left[\left(y_{t}-\mu\right)\left(y_{t+s}-\mu\right)\right]=\gamma_{s}^{2}$, dengan $\gamma_{s}$ adalah kovarians pada lag $s$ yaitu kovarians antara $y_{t}$ dan $y_{t+s}$ dan saat $s=0$, diperoleh $\gamma_{0}$ adalah varians dari $y_{t}\left(\sigma^{2}\right)$.

\section{b. Vector Autoregressive (VAR)}

Model VAR dengan orde $p$ atau $\operatorname{VAR}(p)$ dengan $k$ variabel endogen dapat dituliskan sebagai berikut (Lu $\square$ tkepohl, 2005):

$$
y_{t}=\mu+\Phi_{1} y_{t-1}+\Phi_{2} y_{t-2}+\cdots+\Phi_{p} y_{t-p}+u_{t} \text {, }
$$

untuk $t=0, \pm 1, \pm 2, \ldots$

dengan vektor $y_{t}=\left(y_{1 t}, y_{2 t}, \ldots, y_{K t}\right)^{\prime}$ adalah vektor variabel endogen berukuran $K \times 1, \Phi_{i}$ adalah matriks koefisien berukuran $K \times K$, vektor $\mu=\left(\mu_{1}, \mu_{2}, \ldots, \mu_{K}\right)^{\prime}$ adalah vektor intersep $\quad K \times 1, \quad$ dan vektor $u_{t}=\left(u_{1 t}, u_{2 t}, \ldots, u_{K t}\right)^{\prime}$ adalah vektor error white noise berdimensi $K$ dengan $E\left(u_{t}\right)=0$, $E\left(u_{t} u_{t}^{\prime}\right)=\Sigma_{u}$ dan $E\left(u_{t} u_{s}^{\prime}\right)=0$ untuk $s \neq t$.

\section{c. Uji Akar Unit}

Uji akar unit digunakan untuk menguji kestasioneran data. Uji yang umum digunakan adalah Augmented Dickey-Fuller (ADF), uji ini dibentuk dari model autoregressive (AR) :

$\Delta y_{t}=\beta_{1}+\beta_{2} t+\delta y_{t-1}+\sum_{i=1}^{k} \phi_{i} \Delta y_{t-i}+u_{t}$ dengan menguji hipotesis :

$\mathrm{H}_{0}: \delta=0$ (terdapat akar unit atau data tidak stasioner),

$\mathrm{H}_{1}: \delta \neq 0$ (tidak terdapat akar unit atau data stasioner)

dengan statistik uji $t$ untuk $\delta$ adalah :

$$
t_{\rho}=\frac{\widehat{\delta}}{\text { s.e. }(\widehat{\delta})}
$$

dengan s.e. $(\hat{\delta})$ adalah standard error dari penduga $\delta$.

Hipotesis nol ditolak jika nilai statistik uji $t$ memiliki nilai kurang dari nilai daerah kristis atau $p$-value lebih kecil dari $\alpha$. Penolakan terhadap hipotesis nol berarti bahwa data stasioner.

\section{d. Kointegrasi Johansen}

Model VAR pada persamaan (1) dapat dituliskan dalam bentuk VECM sebagai

$$
\Delta y_{t}=\Pi \mathrm{y}_{\mathrm{t}-1}+\sum_{i=1}^{p-1} \Gamma_{\mathrm{i}} \Delta y_{t-i}+u_{t}
$$
dengan $\Pi=\sum_{i=1}^{p} A_{i}-I$ dan $\Gamma_{\mathrm{i}}=-\sum_{j=i+1}^{p} A_{j}$ Hipotesis dalam uji kointegrasi Johansen adalah sebagai berikut :

$\mathrm{H}_{0}$ : rank $(\Pi) \leq \mathrm{r}$ (terdapat sebanyak $r$ persamaan 
kointegrasi),

$\mathrm{H}_{1}$ :rank $(\Pi)>\mathrm{r} \quad$ (terdapat sebanyak $r+1$

persamaan kointegrasi),

dengan $r=0,1,2, \ldots, k-1$. Dalam uji ini dapat digunakan statistik uji trace

$$
L R_{t r}(r \mid k)=-T \sum_{i=r+1}^{k} \log \left(1-\lambda_{i}\right)
$$

dengan $\lambda_{i}$ adalah nilai eigen ke- $i$ dari matriks П. $\mathrm{H}_{0}$ ditolak jika nilai $L R_{t r}(r \mid k)>$ nilai kritis trace atau $p$-value $<\alpha$, maka uji dilanjutkan untuk $\operatorname{rank}(\Pi)=r+1$ hingga diperoleh $L R_{t r}(r \mid k)<$ nilai kritis trace dengan menerima hipotesis nol yang berarti kointegrasi terjadi pada rank $r$. Sebagai alternatif dapat pula digunakan statistik uji nilai eigen maksimum

$L R_{\text {max }}(r \mid r+1)=-T \log \left(1-\lambda_{r+1}\right)=L R_{t r}(r \mid k)-$

$$
L R_{t r}(r+1 \mid k)
$$

\section{e. Pemilihan Orde Optimum}

Untuk memilih orde lag ( $p$ ) dapat digunakan kriteria informasi seperti Akaike Information Criterion (AIC), Hannan-Quinn Criterion (HQ) dan Schwarz Criterion (SC) yang didefinisikan sebagai berikut:

$$
\begin{aligned}
& \operatorname{AIC}(p)=\log \left|\hat{\Sigma}_{u}\right|+\frac{2 p k^{2}}{T}, \\
& H Q C(p)=\log \left|\hat{\Sigma}_{u}\right|+\frac{2 \log (\log (T)) p k^{2}}{T}, \\
& S C(p)=\log \left|\hat{\Sigma}_{u}\right|+\frac{2 \log (T) p k^{2}}{T},
\end{aligned}
$$

dengan $\widehat{\Sigma}_{u}=\frac{\sum_{t=1}^{T} \widehat{u}_{t} \hat{u}_{t}}{T}, T$ adalah ukuran sampel, dan $k$ adalah jumlah variabel endogen. Nilai $p$ adalah nilai orde optimal yang meminimumkan kriteria informasi.

\section{f. Uji Diagnostik Model}

Uji diagnostik model VAR dapat dilakukan dengan uji portmanteau. Dalam uji portmanteau akan diuji hipotesis

$\mathrm{H}_{0}$ : Tidak terdapat autokorelasi pada residual model dari lag 1 sampai $s$,

$\mathrm{H}_{1}$ : Terdapat paling sedikit satu autokorelasi pada residual model dari lag 1 sampai $s$,

Adapun statistik uji yang digunakan adalah statistik $Q$ sebagai berikut:

$$
Q_{s}=T \sum_{i=1}^{s} \operatorname{tr}\left(\hat{C}_{i}^{\prime} \hat{C}_{0}^{-1} \hat{C}_{i} \hat{C}_{0}^{-1}\right)
$$

dengan $\widehat{C}_{l}=\sum_{t=i+1}^{T} u_{t} u_{t-i}^{\prime}$. Statisik uji ini akan berdistribusi $\chi^{2}\left(k^{2} s-n^{*}\right)$ dengan $n^{*}$ adalah jumlah koefisien selain konstanta dalam model $\operatorname{VAR}(p)$ yang diestimasi. Hipotesis nol ditolak apabila $Q_{h}>\chi^{2}\left(k^{2} s-n^{*}\right)$ atau $p$-value $<\alpha$.

\section{g. Kausalitas Granger}

Kausalitas granger adalah konsep yang menaksir hubungan dinamis antarvariabel ekonomi dalam model VAR. Dalam uji kausalitas granger akan diuji hipotesis

$\mathrm{H}_{0}: X$ tidak granger cause $Y$,

$\mathrm{H}_{1}: X$ granger cause $Y$,

dan statistik uji yang digunakan adalah statistik

$$
F=\frac{\left[\frac{\left(S S R_{r}-S S R_{u}\right)}{n}\right]}{\left[\frac{S S R_{u}}{T-(m+n+1)}\right]}
$$

dengan $S S R_{r}$ dan $S S R_{u}$ berturut-turut adalah jumlah kuadrat residual dari bentuk terestriksi dan tidak terestriksi persamaan (1), $m$ dan $n$ masing-masing adalah jumlah lag pada bentuk terestriksi dan tidak terestriksi. $\mathrm{H}_{0}$ ditolak jika statistik uji $\mathrm{F}>$ nilai kritis $\mathrm{F}$ atau $p$-value $<\alpha$.

\section{h. Impulse Responses Impulse}

Karena masing-masing nilai koefisien dari estimasi model VAR terkadang sulit untuk dinterpretasikan, maka digunakan impulse response function (IRF). IRF menelusuri respon dari variabel dependen dalam ${ }_{(7)}$ istem VAR terhadap guncangan (shock) dalam error $\left(\mathrm{u}_{\mathrm{t}}\right)$ dan mengamati dampak dari gund (hilgan tersebut untuk beberapa periode ke depan.

Dengan melakukan plot IRF secara visual dapat diamati perilaku satu variabel dalam menerima berbagai guncangan (shock) dari variabel lain dalam sistem.

\section{i. Forecast Error Variance Decomposition}

Alat lain yang berguna untuk membantu dalam menelusuri hubungan timbal balik antara variabel-variabel dalam sistem adalah dekomposisi ragam galat peramalan atau forecast error variance decomposition (FEVD). FEVD memberikan informasi mengenai proporsi dari pergerakan suatu proses oleh shocknya sendiri terhadap shock dari variabel lainnya

\section{j. Evaluasi Peramalan}

Salah satu cara mengukur keakuratan hasil peramalan dapat menggunakan mean absolute percentage error (MAPE): 


$$
\mathrm{MAPE}=\sum_{\mathrm{t}=1}^{\mathrm{n}}\left|\frac{\mathrm{y}_{\mathrm{t}}-\widehat{\mathrm{y}_{\mathrm{t}}}}{\mathrm{y}_{\mathrm{t}}}\right| \times \frac{100 \%}{\mathrm{n}}
$$

dengan $y_{t} d a n \widehat{y_{t}}$ berturut-turut adalah nilai data aktual dan nilai hasil peramalan pada waktu ke-t dan $\mathrm{n}$ adalah jumlah data.

Berikut kategori untuk menjadi acuan dari tingkat akurasi MAPE hasil peramalan:

Tabel 1. Kategori Akurasi MAPE

\begin{tabular}{cl}
\hline MAPE & \multicolumn{1}{c}{ Akurasi Peramalan } \\
\hline$<10 \%$ & Hasil peramalan sangat akurat \\
\hline $10 \%-20 \%$ & Hasil peramalan baik \\
\hline $20 \%-50 \%$ & Hasil peramalan masuk akal/wajar \\
\hline$>50 \%$ & $\begin{array}{l}\text { Hasil peramalan lemah atau tidak } \\
\text { akurat }\end{array}$ \\
\hline
\end{tabular}

\section{METODE PENELITIAN}

Data yang akan digunakan adalah data deret waktu (time series) triwulanan PDRB ADHK tahun dasar 2010 Provinsi Bali, pendapatan lapangan usaha akomodasi dan penyediaan makan dan minum tahun 2010-2017 dan data bulanan jumlah kunjungan wisman dan wisnus ke Bali tahun 2010-2017. Data yang digunakan untuk estimasi model adalah data Januari 2010 sampai Juni 2017.

Data dan informasi yang digunakan diperoleh dari Badan Pusat Statistik (BPS) Provinsi Bali melalui website https://bali.bps.go.id dan Dinas Pariwisata Pemerintah Provinsi Bali.

Variabel yang digunakan dalam penelitian ini adalah jumlah kunjungan wisman, PDRB, dan pendapatan industri pariwisata dengan ketiga variabel adalah variabel endogen.

Definisi variabel penelitian dapat dilihat pada Tabel 2.

Tabel 2. Definisi Variabel Penelitian

\begin{tabular}{|c|l|c|}
\hline Variabel & \multicolumn{1}{|c|}{ Keterangan } & $\begin{array}{c}\text { Skala } \\
\text { Pengukuran }\end{array}$ \\
\hline PDRB & $\begin{array}{l}\text { PDRB Provinsi Bali sebagai } \\
\text { proksi pertumbuhan ekonomi }\end{array}$ & Rasio \\
\hline PAR & $\begin{array}{l}\text { Pendapatan lapangan usaha } \\
\text { akomodasi dan penyediaan } \\
\text { makan dan minum sebagai } \\
\text { proksi jumlah pendapatan } \\
\text { industri pariwisata }\end{array}$ & Rasio \\
\hline MAN & $\begin{array}{l}\text { Jumlah kunjungan wisman ke } \\
\text { Bali }\end{array}$ & Rasio \\
\hline NUS & $\begin{array}{l}\text { Jumlah kunjungan wisnus ke } \\
\text { Bali }\end{array}$ & Rasio \\
\hline
\end{tabular}

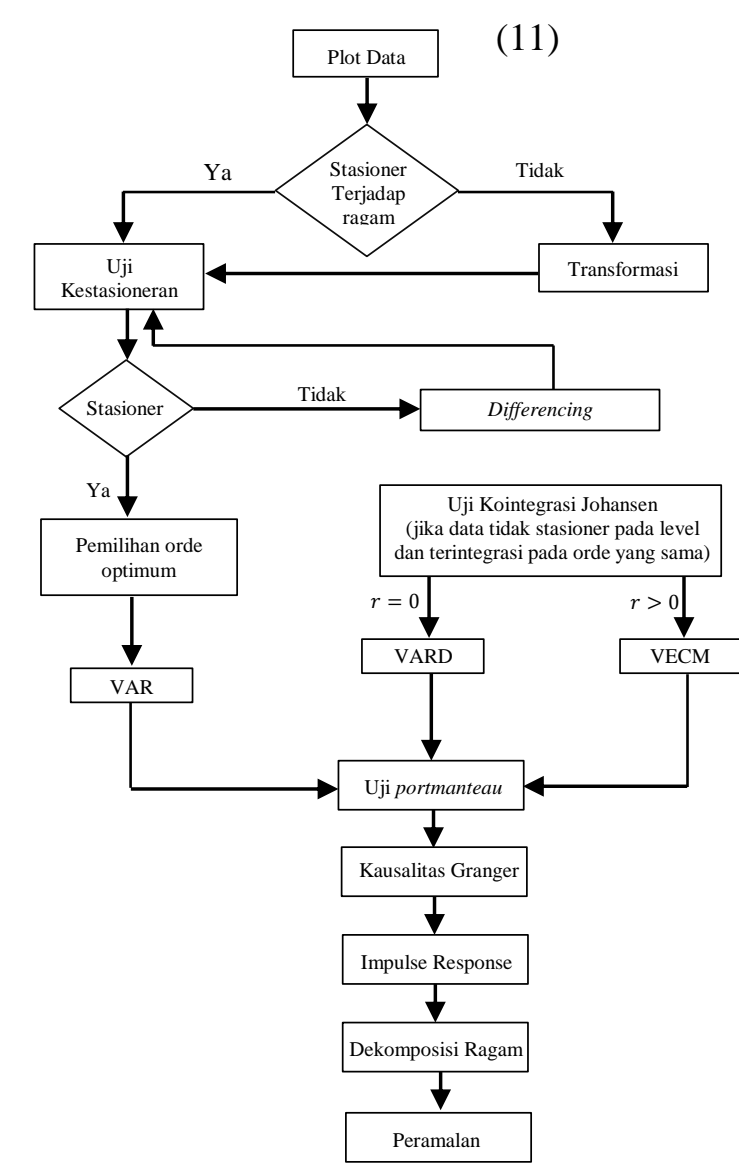

Gambar 1. Diagram Alir Langkah Penelitian

Data maupun informasi yang telah diperoleh akan ditabulasikan dan dilakukan pengolahan data dan analisis dengan menggunakan software Eviews 10. Adapun langkah - langkah yang akan dilakukan dalam penelitian ini adalah sebagai berikut:

1. Melakukan disagregasi data triwulanan menjadi data bulanan menggunakan disagregasi Chow-Lin.

2. Melakukan analisis deskriptif.

3. Pemeriksaan kestastioneran.

4. Pemilihan orde optimum model.

5. Jika data stasioner, maka model yang digunakan adalah VAR. Jika data tidak stasioner dilanjutkan uji kointegrasi Johansen.

6. Melakukan estimasi model.

7. Uji portmanteau.

8. Analisis kausalitas granger.

9. Analisis IRF dan FEVD.

10. Peramalan dan evaluasi hasil peramalan. 


\section{HASIL DAN PEMBAHASAN}

Gambar 2 menunjukkan pola pergerakan dari PDRB Provinsi Bali tahun 2010 hingga 2017. Terlihat bahwa PDRB mengalami tren naik yang disertai beberapa fluktuasi tiap bulannya, pada triwulan pertama tahun 2017 terjadi peningkatan yang cukup tinggi hal ini diduga hal ini diduga disebabkan oleh adanya batas penyetoran amnesti pajak yang berakhir pada akhir bulan Maret 2017 sehingga sumbangan setiap sektor lapangan usaha penyusun PDRB melonjak tinggi.

Pergerakan pendapatan industri pariwisata disaijkan dalam Gambar 3. Sama seperti PDRB, pendapatan industri pariwisata juga memiliki tren naik dengan sedikit fluktuasi tiap bulannya. Hal yang sama terjadi pada awal triwulan tahun 2017 yaitu peningkatan yang cukup drastis.

Jumlah kunjungan wisnus terlihat sangat fluktuatif namun masih dapat dilihat adanya tren naik yang terjadi. Diperhatikan pula meskipun fluktuatif namun terdapat terlihat gejala musiman dimana pada triwulan IV selalu terjadi penurunan setiap tahunnya dan kemudian terjadi peningkatan kembali pada triwulan I tahun berikutnya.

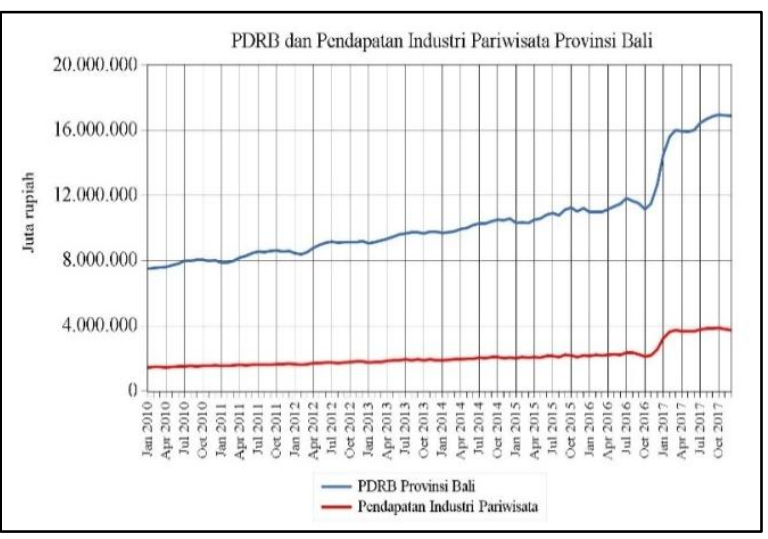

Gambar 2. Plot PDRB dan Pendapatan Industri Pariwisata Januari 2010_Juni 2017

Pergerakan jumlah kunjungan wisman pada Gambar 3 juga menunjukkan adanya tren naik yang cukup jelas terlihat bila dibandingkan dengan jumlah kunjungan wisman. Fluktuasi juga terjadi setiap bulannya namun tidak dapat dilihat dengan jelas terjadi musiman pada jumlah kunjungan wisman

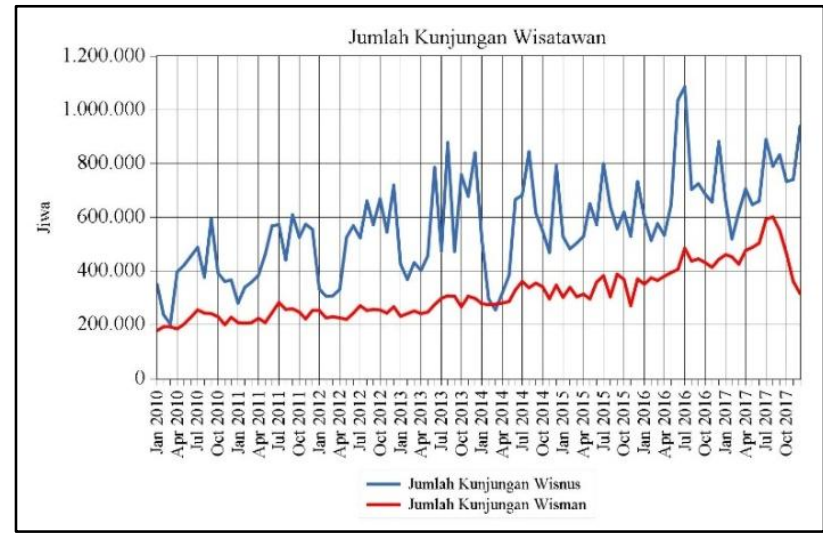

Gambar 3. Plot Jumlah Kunjungan Wisatawan Periode Januari 2010—Juni 2017

\subsection{Spesifikasi, Estimasi dan Pemeriksaan Model}

\section{a. Uji Kestasioneran}

Selain gambaran umum dari pergerakan masing-masing data, plot data menunjukkan adanya gejala bahwa keempat variabel tidak stasioner dalam ragam. Dengan demikia,n dilakukan transformasi logaritma natural (ln) pada keempat variabel, dilanjutkan dengan uji ADF yang disajikan dalam Tabel 3.

Berdasarkan Tabel 3, nilai statistik uji LN_PDRB dan LN_PAR lebih besar dari nilai kritis 5\% atau $p$-value lebih besar dari $\alpha=0,05$ sehingga keputusan adalah terima $\mathrm{H}_{0}$ yang berarti kedua data tersebut tidak stasioner sehingga perlu dilakukan differencing.

Tabel 3. Uji Akar Unit ADF

\begin{tabular}{|c|c|c|c|c|c|}
\hline \multirow{2}{*}{ Variabel } & \multirow{2}{*}{$\begin{array}{c}\text { Nilai } \\
\text { Kritis } \\
\quad(\boldsymbol{\alpha})\end{array}$} & \multicolumn{2}{|c|}{ Level } & \multicolumn{2}{|c|}{ 1st Difference } \\
\hline & & $\begin{array}{c}\text { Statisti } \\
\text { k t }\end{array}$ & $\begin{array}{c}p- \\
\text { value }\end{array}$ & Statistik t & $\begin{array}{c}p- \\
\text { value }\end{array}$ \\
\hline \multirow[t]{2}{*}{$\begin{array}{c}\text { LN_PD } \\
\text { RB }\end{array}$} & $t_{\rho}$ & $-2,2241$ & 0.470 & $-6,4670$ & 0 \\
\hline & $5 \%$ & $-3,4583$ & & $-3,4594$ & \\
\hline \multirow[t]{2}{*}{ LN_PAR } & $t_{\rho}$ & $-2,1660$ & 0.502 & $-6,4332$ & 0 \\
\hline & $5 \%$ & $-3,4583$ & & $-3,4583$ & \\
\hline \multirow[t]{2}{*}{$\begin{array}{l}\text { LN_MA } \\
\mathbf{N}\end{array}$} & $t_{\rho}$ & $-4,4428$ & 0.003 & $-12,037$ & 0 \\
\hline & $5 \%$ & $-3,4578$ & & $-3,4583$ & \\
\hline \multirow[t]{2}{*}{ LN_NUS } & $t_{\rho}$ & $-6,3671$ & 0 & $-6,3671$ & 0 \\
\hline & $5 \%$ & $-3,4588$ & & $-3,4588$ & \\
\hline
\end{tabular}

Sementara itu, LN_MAN dan LN_NUS memiliki $p$-value yang lebih kecil dari 0,05 
sehingga keputusan adalah tolak $\mathrm{H}_{0}$ yang berarti masing-masing data LN_MAN dan LN_NUS stasioner pada level atau $\mathrm{I}(0)$. Keempat variabel menunjukkan kesimpulan yang sama setelah dilakukan differencing yaitu keempat data stasioner pada differencing pertama atau I(1).

Karena diperoleh bahwa ada data yang stasioner pada $\mathrm{I}(0)$ dan ada data yang tidak stasioner pada $\mathrm{I}(0)$, maka tidak terjadi kointegrasi antarvariabel. Hal ini berarti model yang digunakan adalah model VARD yaitu VAR dengan differencing satu kali.

\section{b. Estimasi dan Pemeriksaan Model}

Selanjutnya akan ditentukan orde lag optimum untuk melakukan estimasi model. Berikut adalah hasil perhitungan kriteria informasi:

Tabel 4. Perhitungan Kriteria Informasi

\begin{tabular}{clll}
\hline Lag & \multicolumn{1}{c}{ AIC } & \multicolumn{1}{c}{ SC } & HQ \\
\hline 0 & $-12,57638$ & $-12,45813$ & $-12,52894$ \\
\hline 1 & $-13,80342$ & $-13,2122$ & $-13,56621$ \\
\hline 2 & $-14,8899$ & $-13,82570^{*}$ & $-14,46293$ \\
\hline 3 & $-14,74565$ & $-13,20847$ & $-14,12891$ \\
\hline 4 & $-15,02133$ & $-13,01117$ & $-14,21483$ \\
\hline 5 & $-15,50395$ & $-13,02081$ & $-14,50768$ \\
\hline 6 & $-15,5895$ & $-12,63339$ & $-14,40347$ \\
\hline 7 & $-15,94003$ & $-12,51094$ & $-14,56423$ \\
\hline 8 & $-16,20310 *$ & $-12,30103$ & $-14,63754^{*}$ \\
\hline
\end{tabular}

Tabel 4 menunjukkan AIC dan HQ signfikan pada lag 8 sementara itu SC menunjukkan lag yang signifikan adalah 2 . Mengingat prinsip parsimony, panjang lag 8 adalah terlalu besar karena akan terlalu banyak parameter yang diestimasi sehingga panjang lag yang dipilih adalah 2 .

Dilanjutkan melakukan uji diagnostik model dengan uji portmanteau. karena data yang digunakan untuk estimasi model berjumlah 90 data dan dipilih lag optimum adalah 2 (3 pada level), maka lag autokorelasi antarresidual terbesar adalah 86 sehingga hipotesis nol yang diuji yaitu tidak terdapat autokorelasi pada residual model dari lag 1 sampai 86 .
Diperoleh nilai $Q_{86}=914,5314$ dengan $p$-value $=1,000$ yang dapat dilihat pada Tabel 5 . Karena $p$-value $>0,05$, maka diambil keputusan untuk terima hipotesis nol yang berarti tidak terdapat autokorelasi pada residual model dari lag 1 sampai 86. Dengan demikian model VARD(2) baik atau layak untuk digunakan.

Tabel 5. Uji Portmanteau

\begin{tabular}{ccc}
\hline Lag & Q-Stat & p-value \\
\hline 1 & 5,397579 & --- \\
\hline 2 & 22,14677 & --- \\
\hline 3 & 59,13010 & 0,0000 \\
\hline 4 & 84,13312 & 0,0000 \\
\hline. &. &. \\
\hline. &. &. \\
\hline. &. &. \\
\hline 82 & 910,4922 & 1,0000 \\
\hline 83 & 912,2713 & 1,0000 \\
\hline 84 & 913,6163 & 1,0000 \\
\hline 85 & 914,4548 & 1,0000 \\
\hline 86 & 914,5314 & 1,0000 \\
\hline
\end{tabular}

Berikut adalah hasil estimasi VARD(2):

$$
\begin{gathered}
{\left[\begin{array}{c}
\Delta P D R B \\
\Delta P A R \\
\Delta N U S \\
\Delta M A N
\end{array}\right]=\left[\begin{array}{c}
0,004374 \\
0,005651 \\
0,007796 \\
0,015740
\end{array}\right]+\widehat{\Phi}_{1}\left[\begin{array}{c}
\Delta P D R B_{t-1} \\
\Delta P A R_{t-1} \\
\Delta N U S_{t-1} \\
\Delta M A N_{t-1}
\end{array}\right]} \\
+\widehat{\Phi}_{2}\left[\begin{array}{c}
\Delta P D R B_{t-2} \\
\Delta P A R_{t-2} \\
\Delta N U S_{t-2} \\
\Delta M A N_{t-2}
\end{array}\right]
\end{gathered}
$$

dengan

$$
\begin{array}{r}
\widehat{\Phi}_{1}=\left[\begin{array}{llll}
1,400327 & -0,138441 & -0,001247 & -0,14291 \\
0,951431 & 0,530877 & 0,058828 & -0,28445 \\
-4,408079 & 2,743791 & -0,141805 & -0,496968 \\
1,195692 & -0,906965 & 0,077540 & -0,596816
\end{array}\right] \\
\hat{\Phi}_{2}=\left[\begin{array}{llll}
-0,4657 & -0,1074 & 0,008700 & 0,029969 \\
-0,2625 & -0,4531 & -0,0037 & 0,053849 \\
10,34891 & -6,1016 & -0,2445 & -0,0081 \\
0,435814 & -0,0117 & 0,139563 & -0,4165
\end{array}\right]
\end{array}
$$

\subsection{Analisis Kausalitas Granger}

Hasil perhitungan statistik uji untuk uji kausalitas Granger disajikan dalam Tabel 6 dan Tabel 7 berikut: 
Tabel 6. Kausalitas Granger PDRB

Variabel Dependen

$\triangle$ LN_PDRB

\begin{tabular}{ccc}
\hline Variabel & F & p-value \\
\hline $\boldsymbol{\Delta} \boldsymbol{L} \boldsymbol{N} \_\boldsymbol{P} \boldsymbol{A R}$ & 0,87606 & 0,4203 \\
\hline $\boldsymbol{\Delta} \boldsymbol{L} \boldsymbol{N} \_\boldsymbol{N} \boldsymbol{S}$ & 0,42994 & 0,652 \\
\hline $\boldsymbol{\Delta} \boldsymbol{L}$ N_M $\boldsymbol{A} \boldsymbol{N}$ & 33,9404 & 0,000 \\
\hline
\end{tabular}

Pada Tabel 6 diperoleh bahwa p-value bernilai lebih kecil dari 0,05 sehingga keputusan adalah tolak $\mathrm{H}_{0}$ yang berarti jumlah kunjungan wisman signifikan bepengaruh pada nilai PDRB Provinsi Bali. Sementara itu pendapatan industri pariwisata dan jumlah kunjungan wisnus keduanya memiliki $p$-value lebih besar dari nol sehingga keputusan terima $\mathrm{H}_{0}$ atau pendapatan industri pariwisata dan jumlah kunjungan wisnus tidak memiliki pengaruh signifikan terhadap pertumbuhan PDRB.

Tabel 7. Kausalitas Granger PAR Variabel Dependen $\triangle L N \_P A R$

\begin{tabular}{ccc}
\hline Variabel & F & p-value \\
\hline $\boldsymbol{\Delta} \boldsymbol{L} \boldsymbol{N} \_\boldsymbol{P D} \boldsymbol{R} \boldsymbol{B}$ & 7,91326 & 0,0007 \\
\hline $\boldsymbol{\Delta} \boldsymbol{L} \_\boldsymbol{N} \boldsymbol{U} \boldsymbol{S}$ & 4,32897 & 0,0163 \\
\hline $\boldsymbol{\Delta} \boldsymbol{L} \_\boldsymbol{M} \boldsymbol{A} \boldsymbol{N}$ & 9,50731 & 0,0002
\end{tabular}

Pendapatan industri pariwisata ternyata dipengaruhi oleh perubahan PDRB, jumlah kunjungan wisnus dan jumlah kunjungan wisman. Hal ini ditunjukkan oleh nilai $p$-value variabel $P D R B, P A R$ dan $M A N$ lebih kecil dari 0,05 sehingga diambil keputusan yang sama yaitu tolak $\mathrm{H}_{0}$.

\subsection{Peramalan dan Analisis Struktural}

\section{a. Impulse Response Function}

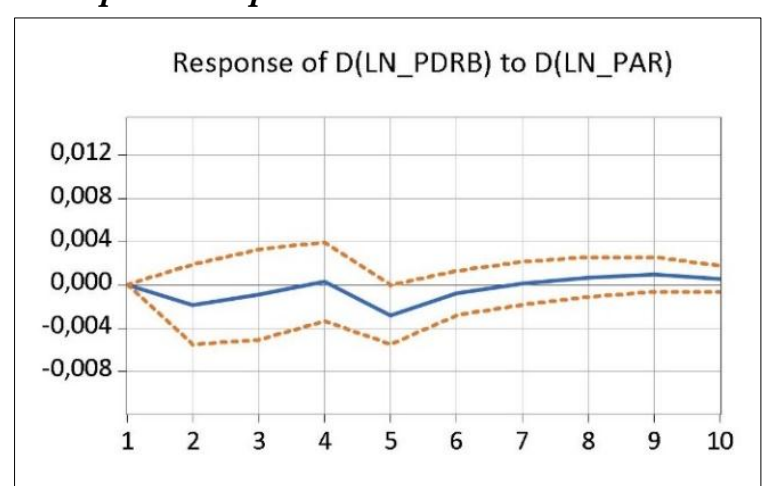

Gambar 4. Plot IRF PDRB terhadap Pendapatan Industri Pariwisata

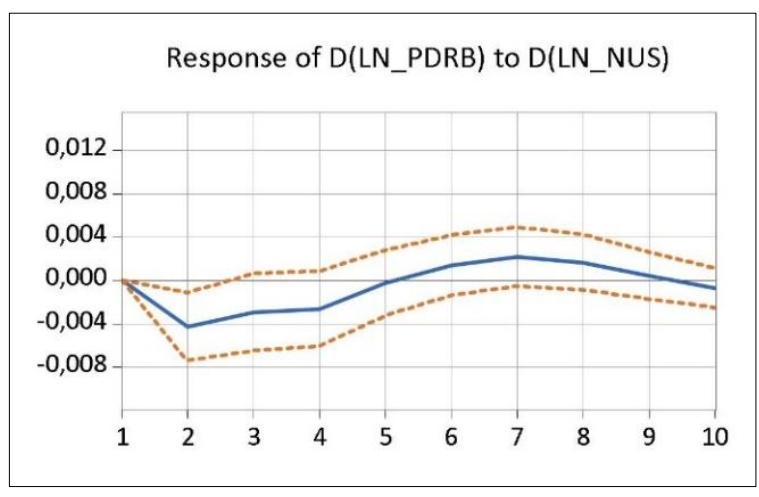

Gambar 5. Plot IRF PDRB terhadap Jumlah

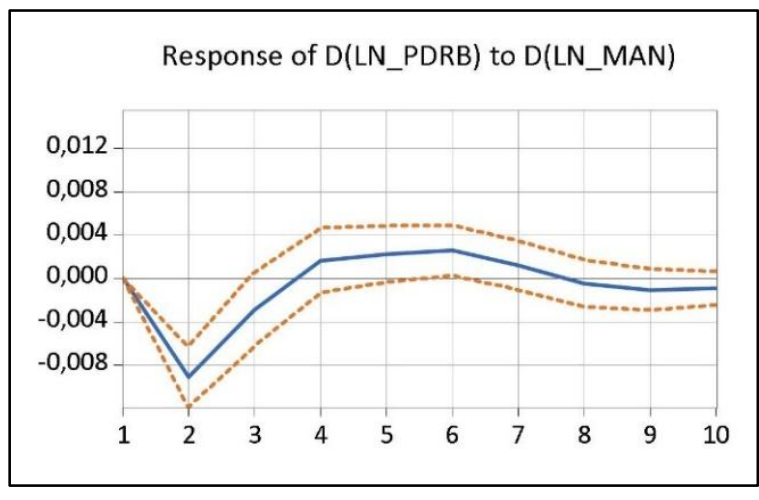

Gambar 6. Plot IRF PDRB terhadap Jumlah Kunjungan Wisman

Pada Gambar 6, shock dari pendapatan industri pariwisata terasa pada periode ke-2, ke3, dan ke-5 yang berturut-turut memberikan pengaruh negatif sebesar 0,$0181 ; 0,00089$; dan 0,002778. PDRB mulai memberikan respon positif terhadap PAR setelah periode ke-7 ini berarti pertumbuhan pendapatan pariwisata baru akan terlihat pengaruhnya dalam mendorong pertumbuhan ekonomi setelah 7 bulan berlalu.

Gambar 7 memberikan gambaran bahwa shock dari jumlah kunjungan wisman menyebabkan efek negatif terhadap PDRB dari bulan ke-2 hingga bulan ke-4 berturut-turut sebesar 0,00423; 0,002906; dan 0,002595 kemudian jumlah kunjungan wisnus baru memberikan dampak positif pada pertumbuhan ekonomi setelah periode ke-5. Respon negatif dari PDRB yang cukup tajam yaitu sebesar 0,009034 disebabkan oleh shock jumlah kunjungan wisman pada periode ke-2 yang ditunjukkan oleh Gambar 8, peningkatan respon PDRB terhadap jumlah kunjungan wisman terjadi setelah bulan ke-4 dan kembali turun setelah periode ke-8. 
Pertumbuhan ekonomi ternyata memberikan dampak yang positif terhadap pendapatan industri pariwisata, hal ini terjadi sejak awal periode hingga periode keempat ini artinya pertumbuhan ekonomi periode sebelumnya akan mendorong pertumbuhan pendapatan industri pariwisata selama 4 periode berikutnya yang dapat diamati pada Gambar 9.

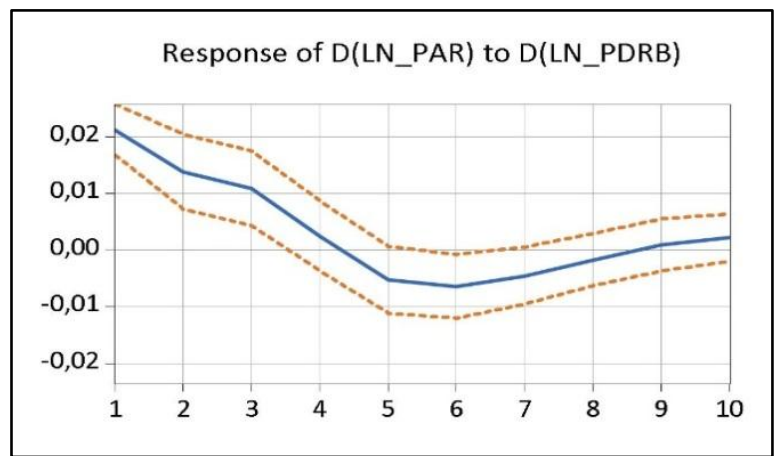

Gambar 8. Plot IRF Pendapatan Industri Pariwisata terhadap PDRB

Kemudian, pada Gambar 10 terlihat jumlah kunjungan wisnus memberikan dampak negatif pada pendapatan industri pariwisata pada periode ke-2 hingga periode ke-5 dan baru memberikan dampak positif pada periode ke-6 yang hanya berlangsung selama 4 bulan yakni hingga periode ke-9. Sementara itu, respon pendapatan industri pariwisata terhadap shock dari jumlah kunjungan wisman ternyata hampir sama dengan respon PDRB terhadap jumlah kunjungan wisman yaitu direspon negatif yang puncaknya terjadi pada periode ke-2 yaitu memberikan penurunan sebesar 0,017982. Jumlah kunjungan wisman baru memberikan dampak yang positif pada industri pariwisata pada periode ke-4 namun kembali turun setelah periode ke- 8 .

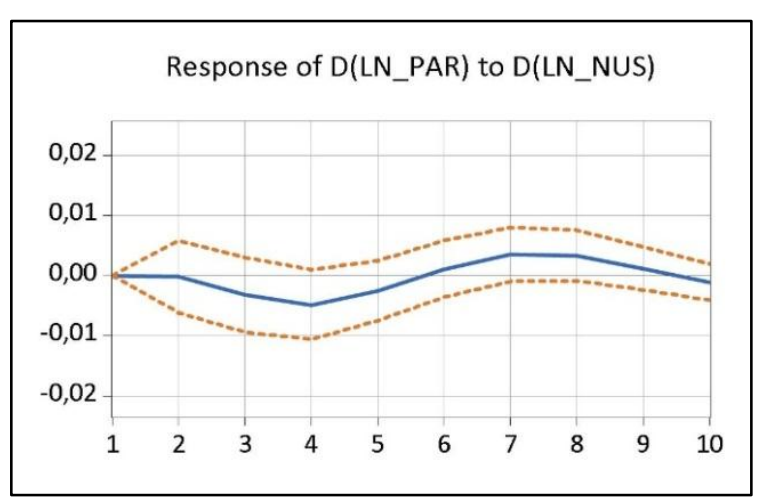

Gambar 9. Plot IRF Pendapatan Industri Pariwisata terhadap Jumlah Kunjungan Wisnus

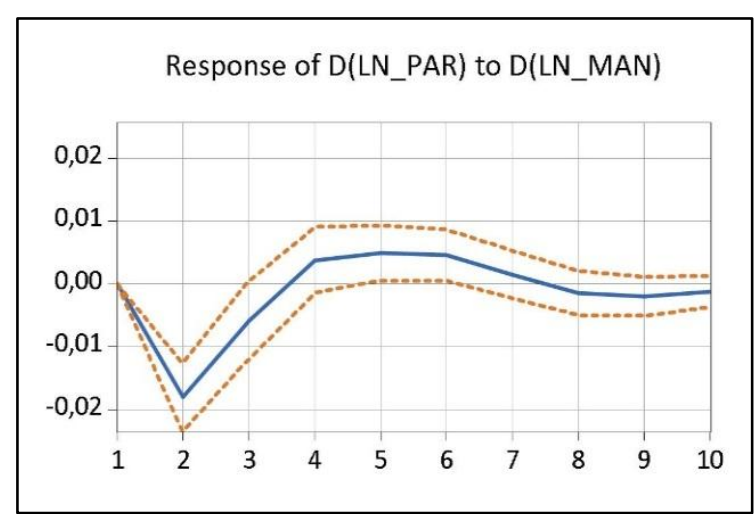

Gambar 7. Plot IRF Pendapatan Industri Pariwisata terhadap Jumlah Kunjungan Wisman

\section{b. Dekomposisi Ragam}

Pada Tabel 8 dapat diamati besarnya kontribusi dari setiap variabel dalam meramalkan variabel $P D R B$ selama 10 periode (bulan) kedepan.

Dapat dilihat kontribusi terbesar terhadap variasi dari nilai PDRB adalah PDRB itu sendiri dengan kontribusi yang diberikan selama 10 periode adalah $69,41 \%-100 \%$, kemudian kontribusi terbesar kedua diberikan oleh jumlah kunjungan wisman yang mencapai $22,46 \%$ sementara itu pendapatan industri pariwisata dan jumlah kunjungan wisnus hanya sedikit memberikan kontribusinya terhadap PDRB.

Di sisi lain, pada Tabel 9 terlihat pertumbuhan pendapatan pariwisata ternyata lebih banyak dijelaskan oleh pergerakan pertumbuhan ekonomi yaitu dengan kontribusi sebanyak 52,5\%-67,9\%. Jumlah kunjungan wisman juga memberikan kontribusi yang relatif besar pada pertumbuhan pendapatan pariwasata dengan kontribusi yang diberikan mencapai $26,72 \%$. Sementara itu, jumlah kunjungan wisnus tidak banyak berkontribusi dalam pertumbuhan pendapatan industri pariwisata ditunjukkan dengan kontribusinya yang relatif kecil hanya mencapai $4 \%$. 
Tabel 8. Dekomposisi Ragam PDRB

\begin{tabular}{ccccc}
\hline Periode & $\boldsymbol{\Delta} \boldsymbol{L} \boldsymbol{N} \_\boldsymbol{P D R B}$ & $\boldsymbol{\Delta} \boldsymbol{L} \boldsymbol{N} \_\boldsymbol{P} \boldsymbol{A R}$ & $\boldsymbol{\Delta} \boldsymbol{L} \boldsymbol{N} \_\boldsymbol{N} \boldsymbol{U} \boldsymbol{S}$ & $\boldsymbol{\Delta} \boldsymbol{L} \boldsymbol{N} \_\boldsymbol{M} \boldsymbol{A N}$ \\
\hline 1 & 100,0000 & 0,000000 & 0,000000 & 0,000000 \\
\hline 2 & 71,70106 & 0,901617 & 4,933475 & 22,46384 \\
\hline 3 & 72,95408 & 0,915908 & 5,938137 & 20,19187 \\
\hline 4 & 71,67719 & 0,907586 & 7,229300 & 20,18593 \\
\hline 5 & 70,35155 & 2,469811 & 6,894499 & 20,28414 \\
\hline 6 & 70,24315 & 2,438110 & 6,888464 & 20,43028 \\
\hline 7 & 70,07824 & 2,358558 & 7,559915 & 20,00329 \\
\hline 8 & 69,73022 & 2,430949 & 8,004279 & 19,83455 \\
\hline 9 & 69,46615 & 2,593463 & 8,002011 & 19,93838 \\
\hline 10 & 69,41359 & 2,632724 & 8,025050 & 19,92864 \\
\hline & & & &
\end{tabular}

Tabel 9. Dekomposisi Ragam PAR

\begin{tabular}{ccccc}
\hline Periode & $\boldsymbol{\Delta L} \boldsymbol{L N}_{-} \boldsymbol{P D R B}$ & $\boldsymbol{\Delta} \boldsymbol{L} \boldsymbol{N} \_\boldsymbol{P} \boldsymbol{A R}$ & $\boldsymbol{\Delta L} \boldsymbol{L} \boldsymbol{N} \boldsymbol{N} \boldsymbol{S}$ & $\boldsymbol{\Delta} \boldsymbol{L} \boldsymbol{N}_{-} \boldsymbol{M} \boldsymbol{A N}$ \\
\hline 1 & 67,94246 & 32,05754 & 0 & 0 \\
\hline 2 & 52,9625 & 20,30569 & 0,002313 & 26,72949 \\
\hline 3 & 55,0464 & 18,28902 & 0,738272 & 25,92631 \\
\hline 4 & 53,73555 & 17,77528 & 2,376466 & 26,1127 \\
\hline 5 & 52,7373 & 18,25909 & 2,671185 & 26,33243 \\
\hline 6 & 53,04721 & 17,79926 & 2,632534 & 26,52099 \\
\hline 7 & 53,16532 & 17,41069 & 3,344137 & 26,07985 \\
\hline 8 & 52,77116 & 17,30802 & 3,990874 & 25,92995 \\
\hline 9 & 52,5138 & 17,41642 & 4,051964 & 26,01782 \\
\hline 10 & 52,53344 & 17,39513 & 4,099898 & 25,97153 \\
\hline & & & &
\end{tabular}

\section{b. Hasil Peramalan}

Hasil peramalan dengan model $\operatorname{VARD}(2)$ selama 6 periode (bulan) kedepan dapat dilihat pada Tabel 10.

Tabel 10. Hasil Ramalan dan Data Aktual PDRB Tahun 2017

\begin{tabular}{lccc}
\hline Periode & $\begin{array}{c}\text { Nilai Aktual } \\
\text { PDRB }\left(\boldsymbol{y}_{\boldsymbol{t}}\right)\end{array}$ & $\begin{array}{c}\text { Hasil Peramalan } \\
\text { PDRB }\left(\widehat{\boldsymbol{y}}_{\boldsymbol{t}}\right)\end{array}$ & $\left|\frac{\boldsymbol{y}_{\boldsymbol{t}}-\widehat{\boldsymbol{y}}_{\boldsymbol{t}}}{\boldsymbol{y}_{\boldsymbol{t}}}\right|$ \\
\hline Juli & $16.427 .534,28$ & $16.165 .707,59$ & 0,015938 \\
\hline Agustus & $16.688 .325,74$ & $16.635 .311,71$ & 0,003177 \\
\hline September & $16.845 .966,00$ & $16.914 .070,61$ & 0,004043 \\
\hline Oktober & $16.958 .915,56$ & $17.182 .864,05$ & 0,013205 \\
\hline November & $16.899 .692,46$ & $17.488 .864,74$ & 0,034863 \\
\hline Desember & $16.877 .733,57$ & $17.389 .574,09$ & 0,030326 \\
\hline \multicolumn{5}{c}{ Total } \\
\hline \multicolumn{5}{c}{ MAPE $=\frac{0,101552}{6} \times 100 \%=2 \%$} \\
\hline
\end{tabular}

Diperoleh nilai MAPE yang cukup kecil yaitu $2 \%$, angka ini termasuk dalam kategori peramalan sangat akurat sehingga hasil peramalan PDRB Provinsi Bali menggunakan model VARD(2) ini dapat dikatakan sangat baik.

\section{KESIMPULAN DAN SARAN}

Berdasarkan uraian pada hasil dan pembahasan, maka diperoleh beberapa kesimpulan, yaitu:
1. Pertumbuhan ekonomi signifikan dipengaruhi oleh jumlah kunjungan wisman ke Bali. Sementara itu, pendapatan industri pariwisata di Bali dipengaruhi oleh pertumbuhan ekonomi Provinsi Bali, jumlah kunjungan wisman, dan jumlah kunjungan wisnus ke Bali.

2. Pertumbuhan ekonomi mendorong peningkatan pendapatan industri pariwisata dengan pada empat bulan pertama periode berikutnya yang artinya pertumbuhan ekonomi pada bulan sebelumnya akan mendorong peningkatan pendapatan industri pariwisata selama empat bulan berikutnya.

3. Model yang diperoleh memberikan hasil peramalan dengan MAPE $2 \%$ yang berarti hasil peramalan sangat baik.

Penelitian ini tidak melibatkan variabel nilai tukar rupiah, inflasi, indeks harga konsumen, dan variabel lain yang mungkin memengaruhi pertumbuhan ekonomi. Pada penelitian selanjutnya diharapkan dapat ditemukan variabel yang memiliki kointegrasi terhadap pertumbuhan ekonomi.

\section{DAFTAR PUSTAKA}

Badan Pusat Statistik Provinsi Bali. (2016). Produk Domestik Regional Bruto Provinsi Bali Menurut Lapangan Usaha 2012-2016. Denpasar: BPS Provinsi Bali.

Badan Pusat Statistik Provinsi Bali. (2017). Bali Dalam Angka 2017. Denpasar: BPS Provinsi Bali.

Enders, W. (2015). Applied Econometrics Time Series. 4th ed. USA: John Wiley \& Sons.

Eviews. (2017). EViews 10 Users Guide. United Kingdom: IHS Markit.

Gujarati, D. N., \& Porter, D. C. (2008). Basic Econometrics. 5th ed. New York: McGrawHill.

$\mathrm{Lu} \square$ tkepohl, H. (2005). Introduction to Multiple Time Series Analysis. Berlin: Springer Verlag.

Rosadi, D. (2012). Ekonometrika dan Analisis Runtun Waktu Terapan dengan Eviews. Yogjakarta: Andi. 